\title{
Isolation and characterization of iridoviruses from the giant toad Bufo marinus in Venezuela
}

\author{
Z. Zupanovic ${ }^{1}$, C. Musso ${ }^{2}$, G. Lopez ${ }^{2}$, C.-L. Louriero ${ }^{2}$, A. D. Hyatt ${ }^{1, *}$, \\ S. Hengstberger ${ }^{1}$, A. J. Robinson ${ }^{3}$ \\ 'Australian Animal Health Laboratory, PO Bag 24, Geelong, Victoria 3220, Australia \\ ${ }^{2}$ Centro de Microbiologia y Biologia Celular, Instituto Venezolano de Investigaciones Cientificas, Apartado Postal 21827, \\ Caracas, Venezuela \\ ${ }^{3}$ Division of Wildlife and Ecology, Commonwealth Scientific and Industrial Research Organisation, PO Box 84, Lyneham, \\ Canberra 2602, Australia
}

\begin{abstract}
In this communication we describe for the first time the isolation of 7 iridoviruses from the toad Bufo marinus and an unknown species of frog Leptodactylus in Venezuela, South America. The viruses are icosahedral with electron-dense cores, each of which is surrounded by an inner membrane, capsid and a cell-derived envelope. The virus(es) have an average vertex to vertex diameter of $160 \mathrm{~nm}$ and replicate in the cytoplasm of a range of cell lines. Within the cytoplasm of infected cells, rarified areas could be observed; structures lacked cellular organelles and contained complete, empty and developing viruses. Results from antigen-capture enzyme-linked immunosorbent assays (ELISA) with polyclonal antibody raised against epizootic haematopoietic necrosis virus (EHNV) indicated crossreactivity between these isolates, Bohle iridovirus (BIV) and frog virus 3 (FV3). Comparison of polypeptide and genomic profiles indicated that the Venezuelan viruses shared many polypeptides of equivalent molecular weight with type species FV3. There were, however, differences between the group of Venezuelan viruses and FV3 and BIV The viruses belongs to the family Iridoviridae and the genus Ranavirus.
\end{abstract}

KEY WORDS: Bufo marinus - Bohle virus · Frog virus $3 \cdot$ Iridovirus · Ranavirus

\section{INTRODUCTION}

The family Iridoviridae encompasses 5 genera: Iridovirus, Chloriridovirus, Ranavirus, Lymphocystivirus and 'goldfish virus 1-like viruses' (Goorha 1995).

Many iridoviruses have been identified in both amphibian and piscine hosts. Piscine iridoviruses have been isolated from redfin perch Perca fluviatilis (epizootic haematopoietic necrosis virus, EHNV) in Australia (Langdon et al. 1986), the catfish Ictalurus melas (Pozet et al. 1992) in France, the sheatfish Silurus glanis (Ahne et al. 1989) in Germany, the ornamental guppy Poecilia reticlata and doctor fish Labroides dimidatus in south-east Asia (Hedrick \& McDowell 1995) and a range of fish from Japan and Thailand (refer to

\footnotetext{
- Addressee for correspondence.

E-mail: alex@aahl.dah.csiro.au
}

Miyata et al. 1997). The amphibian iridoviruses include Bohle iridovirus (BIV) that was isolated in Australia from the ornate burrowing frog Limnodynastes ornatus (Speare \& Smith 1992, Hengstberger et al. 1993), an iridovirus from the common frog Rana temporaria in the United Kingdom (Cunningham et al. 1993, Drury et al. 1995), frog virus 3 (FV3) from the leopard frog Rana pipiens in North America (Granoff et al. 1966), tadpole edema virus (TEV) from the American bullfrog Rana catesbeiana (Wolf et al. 1968), and iridoviruses from Rana esculenta in Croatia (Fijan et al. 1991).

EHNV, FV3, TEV, BIV, sheatfish iridovirus, catfish iridovirus and iridoviruses from guppy and doctor fish cross-react in antigen-capture enzyme-linked immunosorbent assays (ELISAs) using antisera against EHNV (Essani \& Granoff 1989, Hedrick et al. 1992, Hengstberger et al. 1993, Hedrick \& McDowell 1995, Mao et 
al. 1997). The cross-reactivity of these viruses indicated that they probably belong to the same genus, namely Ranavirus. Recent data from Mao et al. (1997) confirm that the Australian iridoviruses, European iridoviruses, and iridoviruses from guppy and doctor fish belong to the genus Ranavirus. These findings suggest that ranaviruses are broadly distributed throughout the world and infect a range of anuran and piscine species.

To date only one iridovirus, an erythrocytic iridovirus, has been detected in Bufo marinus (Speare et al. 1991). This virus is not a recognised member of the Ranavirus genus; it belongs to an undescribed group of erythrocytic iridoviruses. In this report, we describe for the first time the isolation and characterisation of ranaviruses from free-ranging $B$. marinus in Venezuela, South America.

\section{MATERIAL AND METHODS}

Animals and processing of samples. A total of 206 free-ranging toads Bufo marinus and 13 frogs of an unknown species of Leptodactylus were collected from 45 locations in Venezuela during 1992 and 1995 (Table 1). The toad and frogs were sacrificed by cranial pithing. Samples of liver, lung, kidney and spleen were collected and macerated separately. Homogenates (in phosphate buffered saline) were centrifuged at $800 \times g$ for $15 \mathrm{~min}$ at $4^{\circ} \mathrm{C}$ and the resulting supernatant filtered through $0.45 \mu \mathrm{m}$ cellulose membranes and inoculated $(10 \%$ solution) onto tissue culture cells.

Cells and media. Turtle heart subline B1(TH-1, ATCC CCL 50) cells were grown in Basal Eagle's Medium (BME), supplemented with $10 \%$ foetal bovine serum (FBS). Fathead minnow (FHM, ATCC CCL 42) cells were cultured in Eagle's Minimum Essential Medium (EMEM) and 10\% FBS. A6 (kidney, South African clawed toad) cells (ATCC CCL 102) from Xenopus laevis were grown in $75 \%$ NCTC (National Cancer Tissue Culture) 109 medium supplemented with $10 \%$ FBS. Bluegill fry (BF-2 ATCC CCL 81), chinook salmon embryo (CHSE-214, ATCC CRL 1681) and Vero cells (ATCC CCL 81) were grown in EMEM with $10 \%$ FBS. Baby hamster kidney (BHK21) cells, referred to hereafter as $\mathrm{BHK}$ (Commonwealth Serum Laboratories, Mel- bourne, Australia), were grown in EMEM containing $10 \%$ FBS, 10 mM HEPES (N-2-hydroxyethylpiperazine$\mathrm{N}$ ethanesulphonic acid) and $5 \%$ tryptose phosphate broth. All cell lines were kept at $24^{\circ} \mathrm{C}$ (room temperature, RT) and media were supplemented with $10 \mathrm{mM}$ HEPES, $100 \mathrm{U}$ of penicillin and $100 \mu \mathrm{g}$ streptomycin.

Cell inoculations. The supernatants of filtered organ (liver, lung, kidney and spleen) homogenates $(0.2 \mathrm{ml}$

Table 1. Origin, species and number ( $\mathrm{n}$ ) of animals examined

\begin{tabular}{|c|c|c|c|}
\hline Origin (Venezuela) & Coordinates & Species & (n) \\
\hline Altigracia de Orituco & $9^{\circ} 51^{\prime} \mathrm{N}, 66^{\circ} 23^{\prime} \mathrm{W}$ & Bufo marinus & 1 \\
\hline Guatopo National Park & $10^{\circ} 12^{\prime} \mathrm{N}, 66^{\circ} 30^{\prime} \mathrm{W}$ & B. marinus & 24 \\
\hline Boca de Uchire & $10^{\circ} 8^{\prime} \mathrm{N}, 65^{\circ} 26^{\prime} \mathrm{W}$ & B. marinus & 1 \\
\hline Bruzual & $8^{\circ} 5^{\prime} N, 69^{\circ} 21^{\prime} \mathrm{W}$ & B. marinus & 2 \\
\hline Caicara del Orinoco & $7^{\circ} 39^{\prime} \mathrm{N}, 66^{\circ} 11^{\prime} \mathrm{W}$ & B. marinus & 2 \\
\hline Canta Los Gallo & $11^{\circ} 7^{\prime} N_{1} 72^{\circ} 2^{\prime} \mathrm{W}$ & B. marinus & 4 \\
\hline Choroni & $10^{\circ} 31^{\prime} \mathrm{N}, 67^{\circ} 36^{\prime} \mathrm{W}$ & B. marinus & 2 \\
\hline Clarines & $9^{\circ} 57^{\prime} \mathrm{N}, 65^{\circ} 11^{\prime} \mathrm{W}$ & B. marinus & 2 \\
\hline Coro & $11^{\circ} 24^{\prime} \mathrm{N}, 69^{\circ} 41^{\prime} \mathrm{W}$ & B. marinus & 8 \\
\hline Cuao (River Cuao) & $5^{\circ} 19^{\prime} \mathrm{N}, 69^{\circ} 17^{\prime} \mathrm{W}$ & Leptodactylus sp. & 12 \\
\hline Cumana & $10^{\circ} 29^{\prime} \mathrm{N}, 64^{\circ} 12^{\prime} \mathrm{W}$ & B. marinus & 30 \\
\hline Cuyagua & $10^{\circ} 29^{\prime} \mathrm{N}, 67^{\circ} 47^{\prime} \mathrm{W}$ & B. marinus & 2 \\
\hline Tucupita & $9^{\circ} 3^{\prime} \mathrm{N}, 62^{\circ} 4^{\prime} \mathrm{W}$ & B. marinus & 4 \\
\hline El Frio & $7^{\circ} 24^{\prime} \mathrm{N}, 70^{\circ} 29^{\prime} \mathrm{W}$ & B. marinus & 2 \\
\hline Elorza & $7^{\circ} 3^{\circ} \mathrm{N}, 69^{\circ} 30^{\prime} \mathrm{W}$ & B. marinus & 3 \\
\hline El Tigre & $8^{\circ} 54^{\prime} \mathrm{N}, 69^{\circ} 15^{\prime} \mathrm{W}$ & B. marinus & 3 \\
\hline EI Vigia & $8^{\circ} 37^{\prime} \mathrm{N}, 71^{\circ} 39^{\prime} \mathrm{W}$ & B. marinus & 2 \\
\hline Falcon; Buena Vista & $11^{\circ} 56^{\prime} \mathrm{N}, 69^{\circ} 58^{\prime} \mathrm{W}$ & B. marinus & 4 \\
\hline Guiria Sucre & $10^{\circ} 35^{\prime} \mathrm{N}, 62^{\circ} 18^{\prime} \mathrm{W}$ & B. marinus & 2 \\
\hline Higuerote & $10^{\circ} 29^{\prime} \mathrm{N}, 66^{\circ} 7^{\prime} \mathrm{W}$ & B. marinus & 4 \\
\hline La Victoria & $10^{\circ} 13^{\prime} \mathrm{N}, 67^{\circ} 13^{\prime} \mathrm{W}$ & B. marinus & 2 \\
\hline Lagunilla & $8^{\circ} 31^{\prime} \mathrm{N}, 71^{\circ} 24^{\prime} \mathrm{W}$ & B. marinus & 2 \\
\hline Mapire & $7^{\circ} 45^{\prime} \mathrm{N}, 64^{\circ} 43^{\prime} \mathrm{W}$ & B. marinus & 5 \\
\hline Marquarita (Macanao) & $11^{\circ} 4^{\prime} \mathrm{N}, 64^{\circ} 16^{\prime} \mathrm{W}$ & B. marinus & 8 \\
\hline Masaguaral Hata Flores & $8^{\circ} 32^{\prime} \mathrm{N}, 67^{\circ} 28^{\prime} \mathrm{W}$ & B. marinus & 1 \\
\hline $\begin{array}{l}\text { Maturin } \\
\text { Mats }\end{array}$ & $9^{\circ} 45^{\prime} \mathrm{N}, 63^{\circ} 10^{\prime} \mathrm{W}$ & B. marinus & 10 \\
\hline Maturin & $9^{\circ} 45^{\prime} \mathrm{N}, 63^{\circ} 10^{\prime} \mathrm{W}$ & Leptodactylus sp. & 1 \\
\hline Merida (via Los Araquez) & $8^{\circ} 31^{\prime} \mathrm{N}, 71^{\circ} 9^{\prime} \mathrm{W}$ & B. marinus & 6 \\
\hline Paraguana & $12^{\circ} 2^{\prime} \mathrm{N}, 70^{\circ} 3^{\prime} \mathrm{W}$ & B. marinus & 1 \\
\hline Pinero (Hato Pinero) & $9^{\circ} 42^{\prime} \mathrm{N}, 68^{\circ} 58^{\prime} \mathrm{W}$ & B. marinus & 9 \\
\hline Puerto Ayacucho & $5^{\circ} 40^{\prime} \mathrm{N}, 67^{\circ} 39^{\prime} \mathrm{W}$ & B. marinus & 6 \\
\hline Puerto Columbiana & $10^{\circ} 31^{\prime} \mathrm{N}, 67^{\circ} 36^{\prime} \mathrm{W}$ & B. marinus & 22 \\
\hline Puerto la Cruz & $10^{\circ} 32^{\prime} \mathrm{N}, 67^{\circ} 21^{\prime} \mathrm{W}$ & B. marinus & 1 \\
\hline Puerto Piritu & $10^{\circ} 3^{\prime} \mathrm{N}, 65^{\circ} 3^{\prime} \mathrm{W}$ & B. marinus & 1 \\
\hline Quibor & $9^{\circ} 55^{\prime} \mathrm{N}, 69^{\circ} 38^{\prime} \mathrm{W}$ & B. marinus & 2 \\
\hline Sabana Mendoza & $7^{\circ} 3^{\prime} \mathrm{N}, 71^{\circ} 40^{\prime} \mathrm{W}$ & B. marinus & 2 \\
\hline Santa Elena & $4^{\circ} 58^{\prime} \mathrm{N}, 60^{\circ} 55^{\prime} \mathrm{W}$ & B. marinus & 2 \\
\hline San Felipe & $5^{\circ} 11^{\prime} \mathrm{N}, 61^{\circ} 16^{\prime} \mathrm{W}$ & B. marinus & 1 \\
\hline San Felipe (Apure) & $6^{\circ} 53^{\prime} \mathrm{N}, 69^{\circ} 43^{\prime} \mathrm{W}$ & B. marinus & 1 \\
\hline San Juan de los Morros & $9^{\circ} 54^{\prime} \mathrm{N}, 67^{\circ} 22^{\prime} \mathrm{W}$ & B. marinus & 4 \\
\hline San Luis & $10^{\circ} 28^{\prime} \mathrm{N}, 64^{\circ} 11^{\prime} \mathrm{W}$ & B. marinus & 2 \\
\hline Santa Teresa & $10^{\circ} 14^{\prime} \mathrm{N}, 66^{\circ} 4^{\prime} \mathrm{W}$ & B. marinus & 2 \\
\hline Temblador Monages & $9^{\circ} 0^{\prime} \mathrm{N}, 62^{\circ} 38^{\prime} \mathrm{W}$ & B. marinus & 2 \\
\hline Tinaguillo & $9^{\circ} 54^{\prime} \mathrm{N}, 68^{\circ} 19^{\prime} \mathrm{W}$ & B. marinus & 1 \\
\hline Trujillo & $9^{\circ} 22^{\prime} \mathrm{N}, 70^{\circ} 26^{\prime} \mathrm{W}$ & B. marinus & 2 \\
\hline Tucacas edo Falcon & $10^{\circ} 47^{\prime} \mathrm{N}, 68^{\circ} 20^{\prime} \mathrm{W}$ & B. marinus & 1 \\
\hline Universidad Simon BoLivar & $10^{\circ} 30^{\prime} \mathrm{N}, 66^{\circ} 50^{\prime} \mathrm{W}$ & B. marinus & 2 \\
\hline Upata - Bolivar & $8^{\circ} 1^{\prime} \mathrm{N}, 62^{\circ} 24^{\prime} \mathrm{W}$ & B. marinus & 1 \\
\hline Urumaco & $11^{\circ} 12^{\prime} \mathrm{N}_{1} 70^{\circ} 15^{\prime} \mathrm{W}$ & B. marinus & 1 \\
\hline Valle de la Pascua & $9^{\circ} 12^{\prime} \mathrm{N}, 66^{\circ} 1^{\prime} \mathrm{W}$ & B. marinus & 2 \\
\hline Zarasa & $9^{\circ} 20^{\prime} \mathrm{N}, 65^{\circ} 19^{\prime} \mathrm{W}$ & B. marinus & 2 \\
\hline Total & & & 219 \\
\hline
\end{tabular}


well ${ }^{-1}$ ) from individual toads and frogs were added to monolayers of TH-1 and A6 cells in 24-well cluster plates (Nunc). Each inoculum was allowed to adsorb for $1 \mathrm{~h}$ at RT after which it was removed and cells replenished with the corresponding medium. Thereafter, cells were kept at RT and examined daily. At $5 \mathrm{~d}$ post-infection (pi) the culture supernatants were transferred to confluent FHM cell monolayers.

Supernatants from FHM infected cells which displayed a cytopathic effect (CPE) were inoculated onto FHM-, CHSE-, BHK-, Vero- and BF-2 cells. The supernatants were adsorbed for $1 \mathrm{~h}$ at RT and then replaced with the appropriate maintenance media. The supernatants were harvested $7 \mathrm{~d}$ pi and examined by ELISA (refer below).

ELISA. The EHNV-antigen capture ELISA was based on that described by Hyatt et al. (1991). The assay was used to determine whether the isolates from Bufo marinus and Leptodactylus sp. cross-reacted with antisera against EHNV and to evaluate the ability of the isolates to replicate in a range of cell lines (BHK, Vero, FHM, BF-2 and CHSE cells; Hengstberger et al. 1993). Briefly, the coating primary antibody was rabbit anti-EHNV (raised against gradient purified EHNV, isolated from rainbow trout Oncorhynchus mykiss), and the secondary antibody was sheep anti-EHNV (also raised against gradient purified EHNV isolated from rainbow trout) (Hyatt et al. 1991). The antigens (of known TCID50 per ml, refer below) consisted of neat supernatants from FHM cells infected with each of the isolated viruses, BIV and FV3. The substrates and other specifics of the assay are described by Hyatt et al. (1991). Optical densities (OD) were read in a Labsystems Multiscan MS plate reader at $450 \mathrm{~nm}$, and recorded as: (sample OD) - (OD of uninfected cells). The control antigens were EHNV 86/8774 and were used at dilutions of $1: 10,1: 100,1: 500$ and $1: 10000$. The positive-negative values for the ELISA are approximated by the OD value of the 1:500 dilution of the EHNV control (A. D. Hyatt \& R. J. Whittington unpubl. data). The ELISA was also used to assess the ability of the viruses to grow at 18,24 (RT), 26, 30 and $37^{\circ} \mathrm{C}$ in Vero cells.

Electron microscopy. TH-1 cells infected with second passage supernatant were scraped and pelleted at $48 \mathrm{~h}$ pi. Pellets were fixed in phosphate (Sörensen's) buffered $2.5 \%(\mathrm{v} / \mathrm{v})$ glutaraldehyde, washed with Sörenson's buffer $(3 \times 20 \mathrm{~min})$, post-fixed in $1 \%(\mathrm{w} / \mathrm{v})$ osmium tetroxide, dehydrated in ethanol ( 70 to $100 \%$ ), infiltrated with propylene oxide and embedded in Medcast Epon resin. Ultra-thin sections were doublestained in uranyl acetate and lead citrate. Intracellular viruses located within cytoplasmic aggregates and exhibiting a hexagonal outline were measured vertex to vertex. The dimensions of the particles were calculated using a calliper (Mitutoyo Corp. model CD-6"P).
All Venezuelan isolates were inoculated onto gridcell FHM cultures (Hyatt et al. 1987). At $18 \mathrm{~h}$ pi the cultures were negatively stained with $2 \%$ phosphotungstic acid (PTA) adjusted to $\mathrm{pH} 6.8$ with $1 \mathrm{M} \mathrm{KOH}$.

Specimens were examined with a Philips CM10 transmission electron microscope at $80 \mathrm{kV}$ or a Hitachi $\mathrm{H} 7000$ transmission electron microscope at $75 \mathrm{kV}$. The 17000 (used for determining the diameter of the viruses) was calibrated with a 2100 lines $\mathrm{mm}^{-1}$ replica standard.

Pulse radiolabelling and sodium dodecyl sulphate polyacrylamide gel electrophoresis (SDS-PAGE). FHM cells were seeded at $2 \times 10^{5}$ cells well ${ }^{-1}$ in 24 -well Linbro tissue culture (TC) plates. Cells were mock treated or inoculated ( $1 \mathrm{~h}$ ) with tissue culture-passaged viruses ( 7 South American isolates, BIV, and FV3). The infective dose of each virus stock was determined empirically as to produce analogous polypeptide (band) densities in the SDS-PAGE. At $29 \mathrm{~h}$ pi, cells were washed and incubated $30 \mathrm{~min}$ in Met-, Cys-deficient EMEM (ICN Pharmaceuticals, Costa Mesa, CA, USA); this was replaced by deficient EMEM which contained $200 \mu \mathrm{Ci} \mathrm{ml}{ }^{-1}$ of a ${ }^{35} \mathrm{~S}$-Met/Cys mixture (Tran ${ }^{35} \mathrm{~S}$-Label, ICN Pharmaceuticals), and metabolic labelling was performed from 30 to $32 \mathrm{~h}$ pi. Cells were harvested by centrifugation $(14000 \times g, 2 \mathrm{~min})$. Supernatants and cell pellets were frozen in liquid nitrogen and stored at $-20^{\circ} \mathrm{C}$ until separated by SDS-PAGE on 8 to $16 \%$ Trisglycine linear gradient gels (Novex, San Diego, CA, USA) at $120 \mathrm{~V}$. Cell pellets were prepared by resuspension in $20 \mu \mathrm{l}$ of $10 \mathrm{mM}$ Tris- $\mathrm{HCl}, 1 \mathrm{mM}$ EDTA (TE buffer, pH 7.2) containing 2 mM PMSF (phenylmethylsulfonyl fluoride; Sigma Chemical Company, St. Louis, MO, USA), followed by addition of $10 \mu \mathrm{l}$ of $3 \times$ electrophoresis sample buffer (ESB; New England Biolabs, Beverly, MA, USA). Viscosity of lysed cells was reduced by sonication (Braunsonic Model 720) and heated $\left(100^{\circ} \mathrm{C}, 5 \mathrm{~min}\right)$, microfuged briefly, and the cell extract (equivalent to $5 \times 10^{4}$ cells) was loaded into the wells of the gell for electrophoresis. Broad range pre-stained molecular weight standards (New England Biolabs) were used for calibration. Gels were subsequently stained with Commassie Brilliant Blue, then dried and exposed on Kodak BioMax autoradiography film.

DNA purification. Monolayers of CHSE cells (one $150 \mathrm{~cm}^{2}$ flask per virus) were infected with $\left(10^{6} \mathrm{TCID}_{50}\right.$ per ml) FV3, BIV and the 7 South American viruses. When CPEs had reached 70 to $80 \%$, cells were removed from the flask, pelleted $(800 \times g$ for $10 \mathrm{~min})$ and the pellets frozen at $-20^{\circ} \mathrm{C}$. Pellets were thawed, resuspended in $1 \mathrm{ml}$ of TE buffer $(10 \mathrm{mM}$ Tris/ $\mathrm{HCl}, 1 \mathrm{mM}$ EDTA, pH 8) and the virus released from the cell by shearing in a motor-driven Dounce homogeniser (Kontes Glass Co, Vineland, NJ, USA). The resultant homogenate was pelleted $(800 \times g, 10 \mathrm{~min})$ and virus DNA purified from the supernatant $(0.4 \mathrm{ml})$ using a genomic 
DNA purification kit (Qiagen, USA). Isopropanol $(\times 0.7$ vol, RT) was added to the eluted samples. Tubes were inverted 10 times, centrifuged $(10000 \times \mathrm{g})$ for $15 \mathrm{~min}$ and the supernatants carefully removed. Viral DNA was washed with $1 \mathrm{ml}$ of cold $70 \%$ ethanol followed by air drying for $10 \mathrm{~min}$ and resuspended in $50 \mu \mathrm{l}$ of the TE buffer with RNAase A $\left(10 \mu \mathrm{g} \mathrm{ml}^{-1}\right.$, DNase-free Genesearch). To determine the concentration and yield of DNA, $2 \mu$ l of each sample was diluted in $1 \mathrm{ml}$ of TC water [reverse osmosis, sterilised $\left(121^{\circ} \mathrm{C}\right.$, $15 \mathrm{~min}), 18.3 \mathrm{M} \Omega$ ]. The spectrophotometer was calibrated with TC water and the OD of samples measured at $\mathrm{A}_{260}$ and $\mathrm{A}_{280}$. Equivalent concentrations (determined by absorbance, refer above) of DNA were used in the following experiments

Restriction endonuclease hybridisation analyses. Restriction endonuclease (RE) digestion (with HpaII, MspI, BamHI, HindIII and Xbal) and agarose gel electrophoresis were carried out as described by Coupar et al. (1990) and Hengstberger et al. (1993). For hybridisation studies, 3-fold dilutions of sonicated DNA [approximately $0.6 \mu \mathrm{g}$ (initial amount) for each virus isolate, in addition to vaccinia virus (negative control)] in $10 \times \mathrm{SSC}$ (saline sodium citrate buffer) were denatured at $95^{\circ} \mathrm{C}$ for $10 \mathrm{~min}$, cooled on ice and loaded in equivalent con-centrations onto duplicate Gene Screen Plus (NEN) membranes. Membranes were hybridized with nick translated ${ }^{32} \mathrm{P}$-labelled FV3 or the isolate $\mathrm{GV}$ overnight at $42^{\circ} \mathrm{C}$ in buffer containing $50 \%$ formamide. Membranes were washed with $2 \times \mathrm{SSCl}$ $0.1 \%$ sodium dodecyl sulphate (SDS) followed by $0.1 \times$ $\mathrm{SSC} / 0.1 \% \mathrm{SDS}$ at $60^{\circ} \mathrm{C}$ and exposed to X-ray film.

\section{RESULTS}

\section{Isolation of viruses}

Animals exhibited no external lesions or internal signs of disease. No histopathology was performed.

CPE was observed from $\mathrm{TH}-1$ cells inoculated with homogenates from 6 individual Bufo marinus toads and 1 unknown species of Leptodactylus. The isolates are referred to as Cum5, Cum6, Cum30, Mat1, Mat2, GV and Mg1 (Table 2). The CPE was generally observed 4 d pi in TH-1 cells inoculated with tissue homogenates. CPE was initially identified by the presence of scattered clusters of round and refringent cells followed by the formation of punctate plaques. The CPE expanded over the course of infection until the remaining cells detached from the substrate. In contrast, the CPE in A6 cells took longer, generally $6 \mathrm{~d}$ pi, and consisted of patches of rounded cells forming indistinct plaques. CPE in the form of punctate plaques was also identified after 2 passages in FHM cells.
Table 2. Species and geographical locations from which viruses were isolated

\begin{tabular}{|lll|}
\hline Species & $\begin{array}{l}\text { Name of } \\
\text { isolate }\end{array}$ & $\begin{array}{l}\text { Name of location } \\
\text { in Venezuela }\end{array}$ \\
\hline $\begin{array}{l}\text { Bufo marinus } \\
\text { Bufo marinus }\end{array}$ & Cum5 & Cumana \\
$\begin{array}{l}\text { Bufo marinus } \\
\text { Leptodactylus sp. }\end{array}$ & Cum30 & Cumana \\
$\begin{array}{l}\text { Bufo marinus } \\
\text { Bufo marinus }\end{array}$ & Mat2 & Maturin \\
Bufo marinus & GV & Maturin \\
\hline
\end{tabular}

\section{Electron microscopy}

Thin section analysis of glutaraldehyde-fixed infected TH-1 cells revealed the presence of cytoplasmic paracrystalline arrays of icosahedral viruses (Fig. 1A). The arrays were located both within rarified areas of the cytoplasm and in the surrounding cytoplasm. The cytoplasmic viruses were observed at different stages of assembly, ranging from complete icosahedral particles containing electron-dense cores to incomplete particles containing empty to partially full cores. The average diameter for each of the intracellular viruses of Bufo marinus (determined from ultra-thin sections of infected cells) was approximately $160 \mathrm{~nm}$ (Table 3) from vertex to vertex. The average diameter of mature viruses within the unknown Leptodactylus species was $168 \pm 8 \mathrm{~nm}(\mathrm{n}=102)$ from vertex to vertex (Table 3 ). Viruses were also observed budding from the infected cells (Fig. 1B), where they acquired a host-derived membrane that encapsulated the virus. No particles were observed inside the cell nuclei. Examination of infected grid-cell cultures (Fig. 1C) revealed the presence of large numbers of icosahedral viruses adsorbed to the grid substrate. The viruses possessed an outer envelope, a capsid that, in turn, was surrounded by an inner membrane

\section{ELISA}

FHM, Vero, BHK, BF-2 and CHSE cells were inoculated with each of the virus isolates (Table 2) and control virus (FV3). At $7 \mathrm{~d}$ pi the supernatants were examined in the EHNV-capture ELISA. TCID 50 values per $\mathrm{ml}$ for GV, Mat1, Mat2, Cum5, Cum6, Cum30, Mg1 and FV3 were $10^{52}, 10^{5.9}, 10^{5.5}, 10^{5.0}, 10^{6.5}, 10^{5.2}, 10^{6.7}$ and $10^{4.7}$ respectively. The ELISA results (Fig. 2) show that most virus isolates replicate (OD positive-negative cutoff 0.3 , data not shown) in each of the cell lines at $24^{\circ} \mathrm{C}(\mathrm{RT})$. The one exception was FV3 in BF- 2 cells

The Venezuelan viruses, represented by GV, replicated at 18 to $30^{\circ} \mathrm{C}$, but not at $37^{\circ} \mathrm{C}$ (Fig. 3). These 


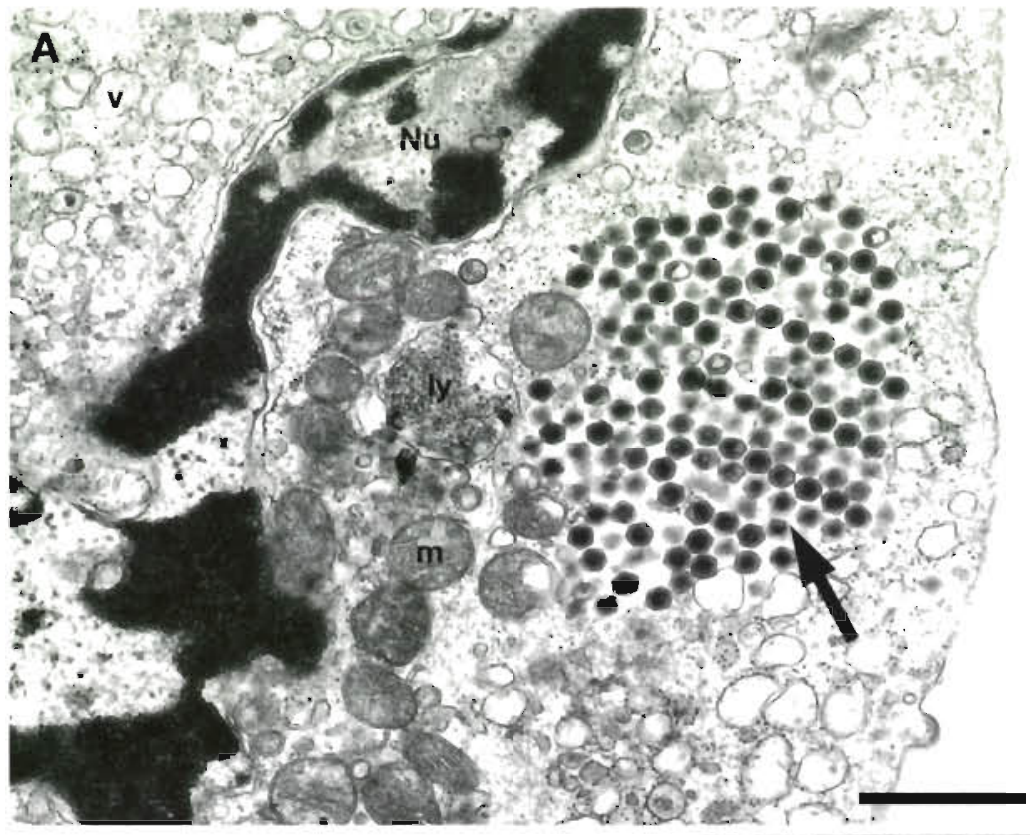

Fig. 1 Transmission electron micrographs of Guatopo virus-infected cells. (A) Cytoplasmic array of icosahedral viruses (large arrow). Nu: nucleus; m: mitochondrion; ly: lysozome; $v$ : distended vesicles of the endoplasmic reticula. Scale bar $=1 \mu \mathrm{m}$. (B) Virus budding (arrow) from the plasma membrane of an infected cell. Scale bar = $100 \mathrm{~nm}$. (C) Negative staining of GV Arrowhead: cell-derived envelope; small arrow: capsid; large arrow: inner de novo membrane. Scale bar $=100 \mathrm{~nm}$

\section{B}

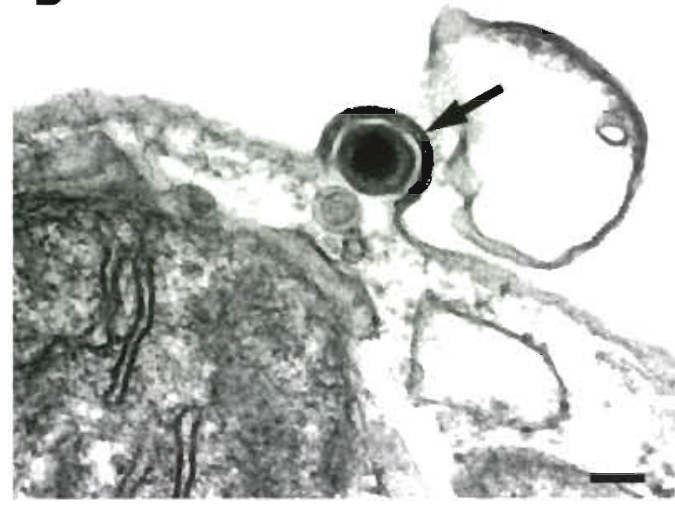

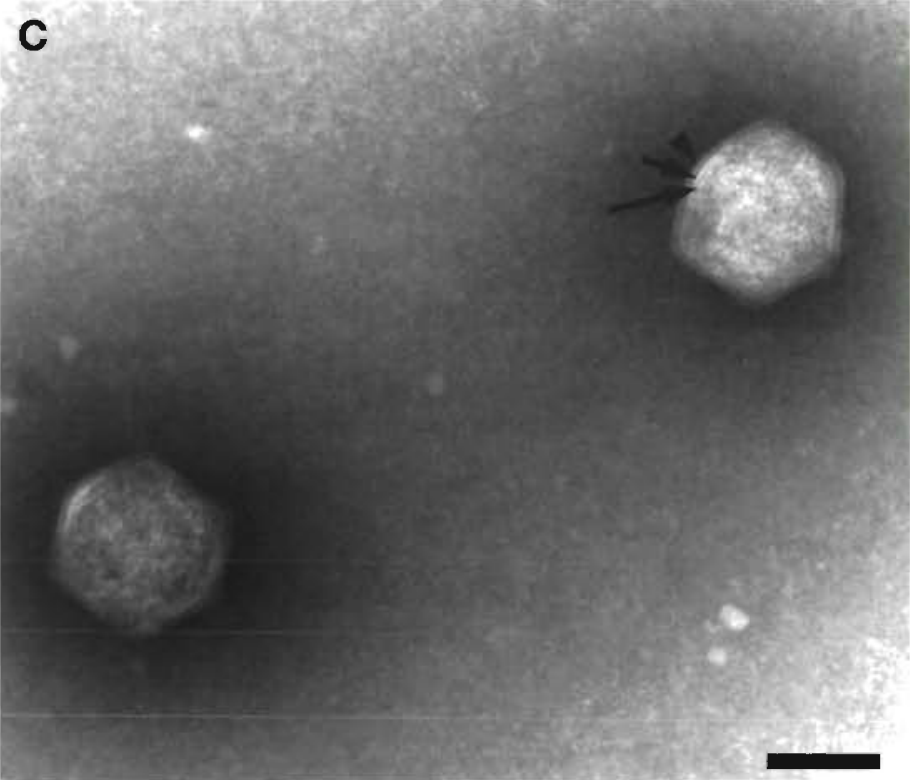

Table 3. Average diameter (vertex to vertex) of BIV, FV3 and the Venezuelan isolates. All measurements were derived from complete virions within cytoplasmic virus arrays. n: number of viruses analysed; SD: standard deviation

\begin{tabular}{|lcc|}
\hline $\begin{array}{l}\text { Name of } \\
\text { isolate }\end{array}$ & $\mathrm{n}$ & $\begin{array}{c}\text { Average diameter } \\
(\mathrm{nm}) \pm \mathrm{SD}\end{array}$ \\
\hline Cum5 & 91 & $156 \pm 6$ \\
Cum6 & 90 & $157 \pm 9$ \\
Cum30 & 62 & $154 \pm 7$ \\
Mat1 & 102 & $168 \pm 8$ \\
Mat2 & 96 & $157 \pm 8$ \\
GV & 78 & $160 \pm 8$ \\
Mg1 & 73 & $153 \pm 8$ \\
BIV & 73 & $155 \pm 8$ \\
FV3 & 100 & $168 \pm 6$ \\
\hline
\end{tabular}

results are similar to those derived from FV3-infected cells incubated at similar temperatures (Fig. 3). The replication of $F V 3$ differed from $G V$ in that the $O D$ from infected cells was comparatively less at $18^{\circ} \mathrm{C}$ (Fig. 3).

\section{Protein composition of purified South American viruses}

Fig. 4 shows intracellular virus-specific proteins of FV3, BIV and the 7 Venezuelan virus isolates metabolically labelled at late times pi. Each virus isolate possessed a minimum of 20 distinguishable polypeptides ranging from approximately 8 to $121 \mathrm{kDa}$. The poly- 


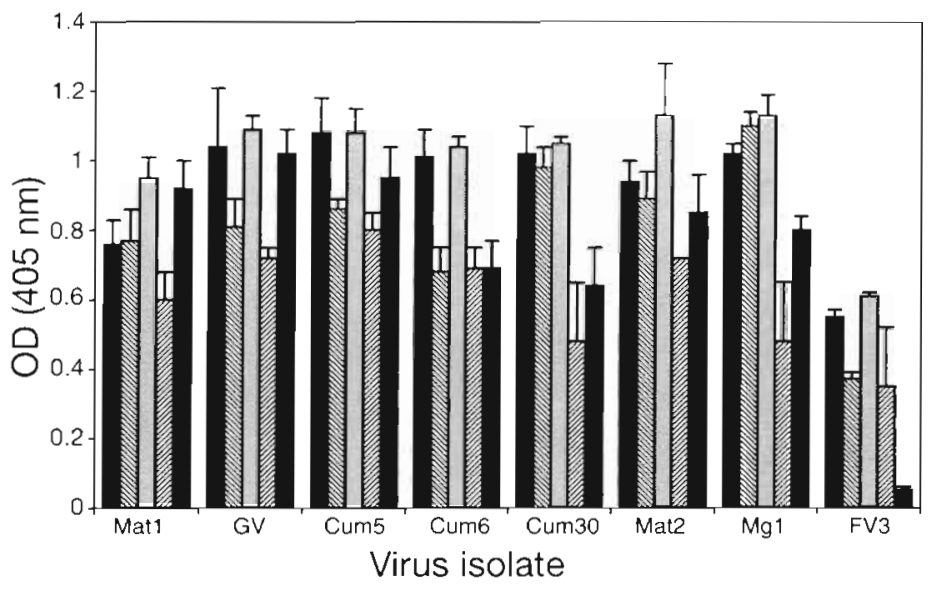

Fig. 2. Results (optical densities, OD) from an EHNV antigen-capture ELISA in which the supernatants from infected (Venezuelan viruses and FV3) CHSE-, FHM-, Vero-, BHK-, and BF-2 cells were analysed. Cells were maintained at $24^{\circ} \mathrm{C}$ (RT). Supernatants were harvested $7 \mathrm{~d}$

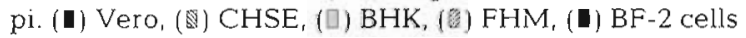

peptide profiles for the Venezuelan virus isolates were very similar and each possessed a major polypeptide of approximately $49 \mathrm{kDa}$ that is characteristic for ranaviruses. Whilst there was an overall similarity between isolates, Cum30 and Mat1 differed in that both possessed a $78 \mathrm{kDa}$ polypeptide; Mat1, however, lacked a $29 \mathrm{kDa}$ polypeptide, which was present in Cum30, BIV and FV3.

Collectively, the polypeptide patterns of the Venezuelan isolates were similar to the amphibian viruses BIV and FV3, i.e. all viruses possessed many polypeptides of equivalent molecular weights (e.g. 65, 59, 49, $45,41,34,32,28,24,17$ and $12 \mathrm{kDa}$ ). The Venezuelan isolates, however, differed to BIV by the absence of a

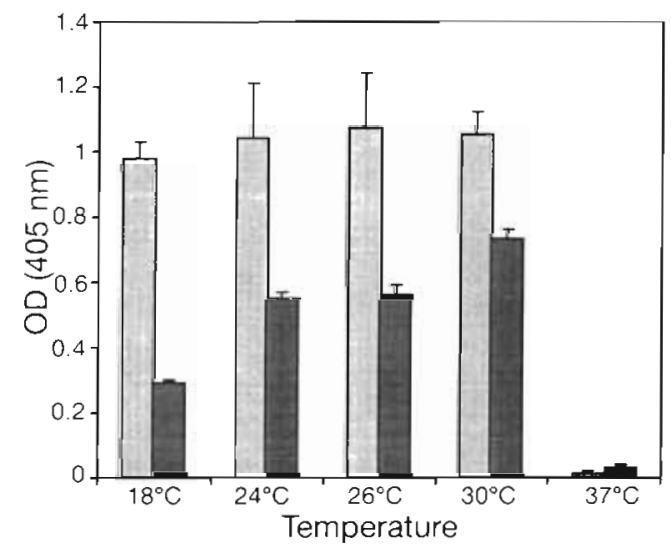

Fig. 3. Results (optical densities, OD) from an EHNV antigencapture ELISA in which the supernatants from infected (GV and FV3) Vero cells were analysed. The cells were maintained at $18,24(\mathrm{RT}), 26,30$ and $37^{\circ} \mathrm{C}$. Supernatants were harvested 7 d pi. (0) GV; (1) FV3 prominent $72 \mathrm{kDa}$ polypeptide and to both BIV and FV3 in the polypeptide pattern within the region of 103 and $78 \mathrm{kDa}$. In this band of polypeptides, the Venezuelan viruses possessed a similar profile $(90,98,103$ and $121 \mathrm{kDa})$. Most Venezuelan isolates also possessed a $76 \mathrm{kDa}$ protein (with the exception of Cum30 and Mat1). Similarly, most Venezuelan isolates possessed a $78 \mathrm{kDa}$ polypeptide with the possible exception of Cum6. BIV and FV3, however, had different polypeptide patterns within this molecular weight range (Fig. 4), the most noticeable difference being the absence of the 90 and $98 \mathrm{kDa}$ polypeptides.

\section{Restriction endonuclease digestion and hybridization analyses}

Fig. 5A, B, C shows RE digestion profiles for DNA isolated from the 7 Venezuelan viruses, BIV and FV3. Digestion of DNA from the Venezuelan viruses with $B a m H I$, Hind III and $X b a I$ resulted in similar fragments. These profiles were different from those produced by the digestion of DNA of BIV with $B a m H I$, Hind III, XbaI and from the digestion of DNA of FV3 with Hind III, and XbaI.

Nucleic acid from the 7 Venezuelan viruses was also digested with HpaII and MspI. Both enzymes identify

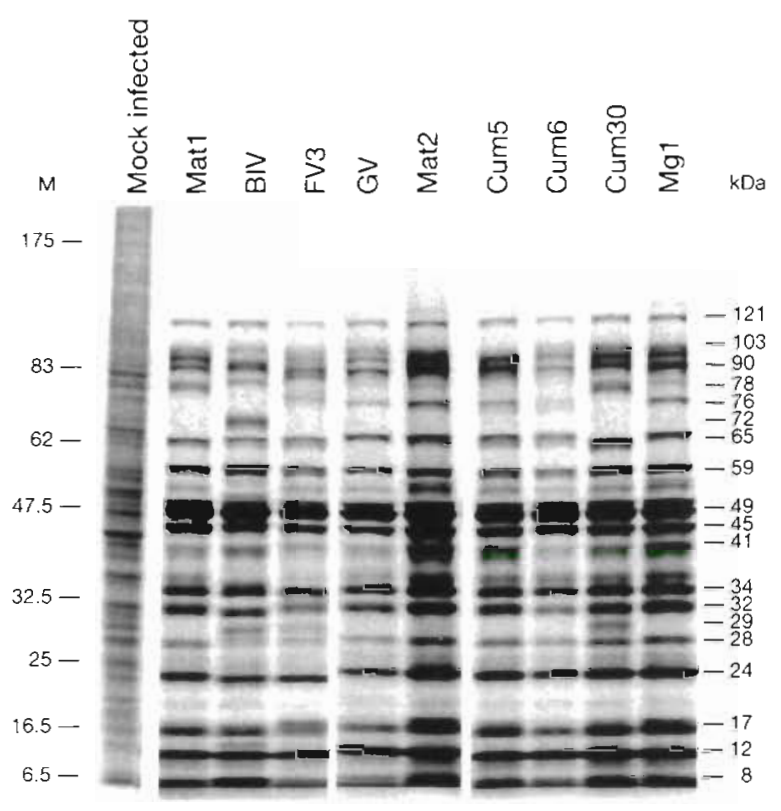

Fig. 4. Autoradiograph of a 10 to $20 \%$ SDS-PAGE of ${ }^{35} \mathrm{~S}$ methionine labelled intracellular proteins harvested from BIV, FV 3 and Venezuelan virus-infected FHM cells. Molecular weights $(\mathrm{kDa})$ were estimated by reference to stained markers (M) 


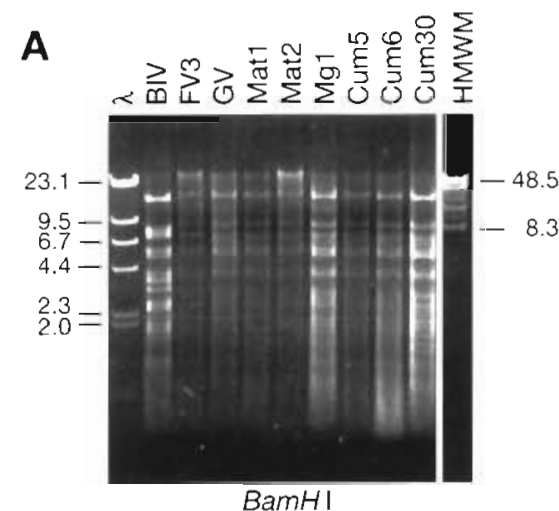

$\mathrm{BamHI}$

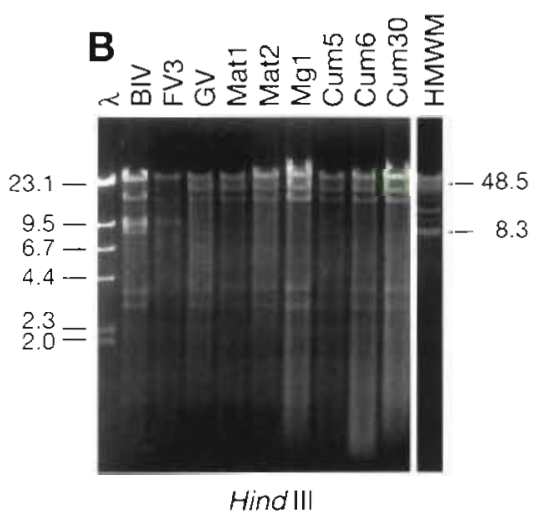

Hindlll

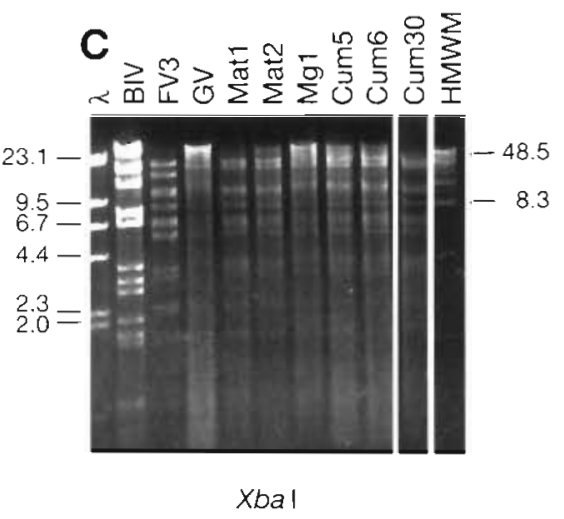

Xbal
Fig. 5. Restriction endonuclease digestion profiles for BIV FV3 and the Venezuelan isolates. Viruses digested with (A) BamHl; (B) Hind III, or (C) XbaI. (D) Viruses incubated with MspI (a) and HpaII (b). Low molecular weight markers were $\lambda$ DNA digested with Hind III $(23.1,9.42,6.68,4.36,2.32$, and $2.03 \mathrm{~kb}$ ) and high molecular weight markers (HMWM) were $\lambda$ markers $(48.5,38.4,33.5,29.9,24.8,22.6,19.4,17.1,15.0,12.2$, $10.1,8.6$ and $8.3 \mathrm{~kb}$ )

the same CCGG sequence, however only MspI can cleave this sequence when the internal cytosine is methylated. Fig. 5D shows that the DNA from all Venezuelan virus isolates were digested with $M s p I$ but resistant to HpaII, thereby indicating that the genomes of all isolates were methylated.

The hybridisation of DNA of virus isolates with nick translated ${ }^{32} \mathrm{P}$-labelled FV3 and GV DNA is shown in Fig. 6. The blots were washed under high stringency conditions and all DNA preparations, except that from vaccinia virus, hybridised, thereby showing a high level of sequence homology. As the concentrations of DNA used in this experiment were approximate, no inferences are made from the intensities of the individual spots.

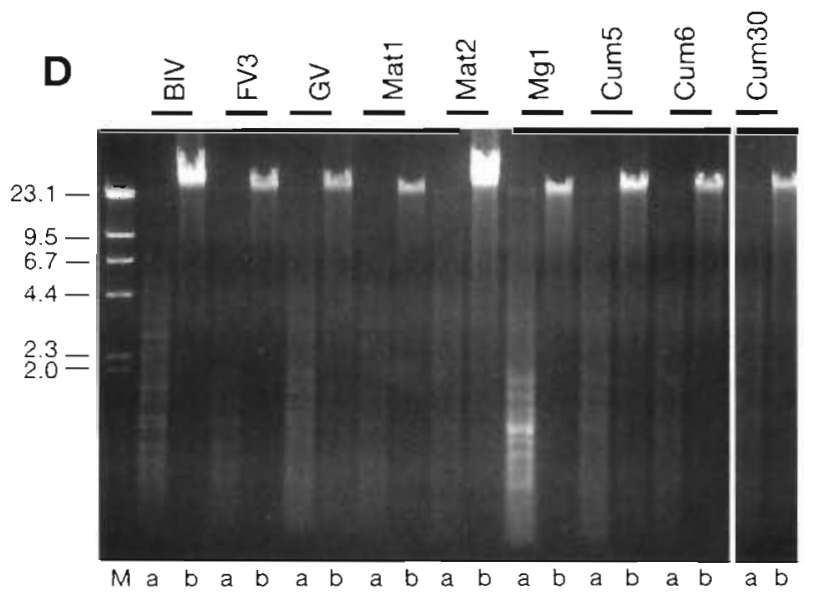

\section{DISCUSSION}

Data from the EHNV antigen-capture ELISA indicated that the Venezuelan viruses described in this paper share many characteristics with ranaviruses. The viruses possess cross-reactive epitopes with BIV and FV3. The ultrastructure of infected cells, such as the presence of rarified cytoplasmic inclusions, cytoplasmic paracrystaline virus arrays and viruses budding from the host cell plasma membrane, is characteristic for replicating ranaviruses (Tripier et al. 1974, Murti et al. 1985, Eaton et al. 1991, Hengstberger et al. 1993). The ability of the viruses to replicate in a range of piscine and amphibian cell lines was also characteristic for ranaviruses (Hengstberger et al. 1993). GV,
Fig. 6. Three-fold dilutions of DNA (approximately 6,2 and $0.7 \mu \mathrm{g}$ ) from BIV, FV3 and the Venezuelan viruses. All DNA were hybridised with ${ }^{32} \mathrm{P}$-labelled DNA of (A) FV3 or (B) GV. Vaccinia virus, used as a control, did not crosshybridize and is not shown

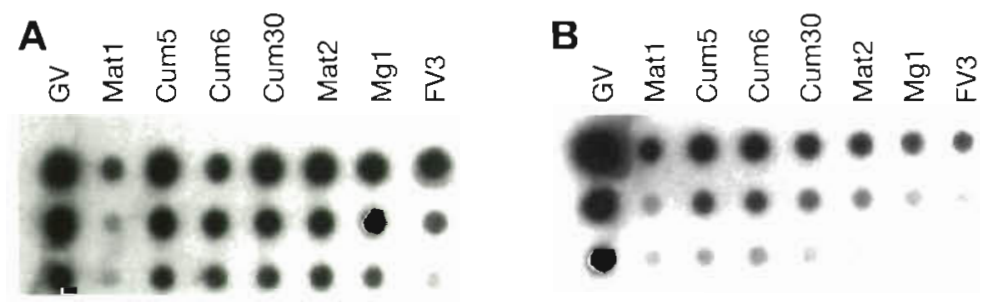


representative of the Venezuelan viruses, replicated at temperatures from 18 to $30^{\circ} \mathrm{C}$ and unlike FV 3 did not show an optimum temperature (from approximately 24 to approximately $30^{\circ} \mathrm{C}$ ) for replication. Neither FV3 or GV replicated at $37^{\circ} \mathrm{C}$ this is a characteristic of the ranavirus type species FV3 (Gravell \& Granoff 1970). Examination of the viral proteins indicates that the Venezuelan virus isolates were very similar. These isolates shared many proteins with BIV and FV3 but lacked the $72 \mathrm{kDa}$ present in BIV. The Venezuelan isolates also differed from both BIV and FV3 in the presence of different high molecular weight proteins. The methylated genomes of the isolates were characteristic for ranaviruses (Essani \& Granoff 1989). The RE restriction digestion profiles for the Venezuelan isolates were very similar but are distinct from BIV and FV3.

The above data indicate that the Venezuelan viruses belong to the genus Ranaviruses within the family Iridoviridae. This inference is supported by the hybridisation data that showed a high degree of homology between the genomes of the Venezuelan isolates and FV3. The data derived from RE digestion of the DNA of all Venezuelan isolates suggest that the Venezuelan isolates are very similar. Sequencing of the isolates will determine whether these isolates are one species.

This is the first report of a ranavirus isolated from Bufo marinus and the first report of a ranavirus being isolated from an aquatic animal in South America. The isolation of GV is also of importance because it indicates that ranaviruses are present on most continents, i.e. North America (Essani \& Granoff 1989), Australia (Hengstberger et al. 1993), Europe (Ahne et al. 1989, Fijan et al. 1991, Mao et al. 1997), Asia (Hedrick \& McDowell 1995, Mao et al. 1997) and South America. Other viruses tentatively identifed as ranaviruses have been identified in the United Kingdom (Cunningham et al. 1993, Drury et al. 1995) and in Japan. Hong Kong, Singapore and Thailand (Miyata et al. 1997).

Many of the viruses tentatively assigned as ranaviruses cause systemic diseases in fish and amphibians (Ahne et al. 1997). For example, BIV can, under experimental conditions, cause disease in multiple species of fish and amphibians, including barramundi Lates calcarifer, the toad Bufo marinus (Moody \& Owens 1994), the ornate burrowing frog Limnodynastes ornatus (Speare \& Smith 1992) and L. terraereginae and Litoria latopalmata (Cullen et al. 1995). Antibodies against ranaviruses have been detected in $B$. marinus populations in Australia and Venezuela (Zupanovic et al. 1998). This information together with the knowledge that GV can, under experimental conditions, cause disease in B. marinus (A. D. Hyatt \& H. Parkes unpubl. results) suggests that $B$. marinus may be both a host and vector for ranaviruses such as GV.
Acknowledgements. This project was conducted at the Centro de Microbiologia y Biologia Celular, Instituto Venezolano de Investigaciones Cientificas, Caracas, Venezuela, with funding from the Australian Government and administration from CSIRO, Division of Wildlife and Ecology, Canberra. The authors thank Ms S. Daglas and Mr Alex Sanchas for their assistance during this study.

\section{LITERATURE CITED}

Ahne $W$, Bremont $M$, Hedrick RP, Hyatt AD, Whittington RJ (1997) Iridoviruses associated with epizootic haematopoietic necrosis (EHN) in aquaculture. World J Microbiol Biotechnol 13:367-373

Ahne W, Schlotfeldt HJ, Thomsen I (1989) Fish viruses: isolation of an icosahedral cytoplasmic deoxyribovirus from sheatfish (Silurus glanis). J Vet Med B 36:333-336

Coupar BEII, Teo T, Boyle DB (1990) Restriction endonuclease mapping of the fowlpox virus genome. Virology 179 $159-167$

Cullen BR, Owens L, Whittington RJ (1995) Experimental infection of Australian anurans (Limnodynastes terraereginae and Litoria latopalmata) with Bohle iridovirus. Dis Aquat Org 23:83-92

Cunningham AA, Langton TES, Bennett PM, Drury SEN, Gough RE, Kirkwood JK (1993) Unusual mortality associated with poxvirus-like particles in frogs (Rana temporaria). Vet Rec 133:141-142

Drury SEN, Gough RE, Cunningham AA (1995) Isolation an iridovirus-like agent from common frogs (Rana temporaria). Vet $\operatorname{Rec} 137: 72-73$

Eaton BT, Hyatt AD, Hengstberger SG (1991) Epizootic haematopoietic necrosis virus: purification and classification. J Fish Dis 14:157-169

Essani K, Granoff A (1989) Amphibian and piscine iridoviruses proposal for nomenclature and taxonomy based on molecular and biological properties. Intervirology 30:187-193

Fijan N, Matasin Z, Petrinec Z, Valpotic 1, Zwillenberg LO (1991) Isolation of an iridovirus-like agent from the green frog (Rana esculenta L). Vet. Arch Zagreb 3:151-158

Goorha R (1995) Virus taxonomy: the classification and nomenclature of viruses. In: Murphy FA, Fauquet $\mathrm{CM}_{\text {, }}$ Bishop DHL, Ghabrial SA, Jarvis AW, Martelli GP, Mayo MA, Summers MD (eds) The 6th Report of the International Committee on Taxonomy of Viruses. SpringerVerlag, Vienna, p 95-99

Granoff A, Came PE, Breeze DC (1966) Viruses and renal carcinoma of Rana pipiens. I. The isolation and properties of virus from normal and tumor tissue. Virology 29:133-148

Gravell M, Granoff A (1970) Viruses and renal adenocarcinoma of Rana pipiens. IX. The influence of temperature and host cell on replication of frog polyhedral cytoplasmic deoxyribovirus (PCDV). Virology 41:596-602

Hedrick RP, McDowell TS (1995) Properties of iridoviruses from ornamental fish. Vet Res 26:423-427

Hedrick RP, McDowell TS, Ahne W, Torhy C, Kinkelin PDe (1992) Properties of three iridovirus-like agents associated with systemic infections of fish. Dis Aquat Org 13:203-209

Hengstberger SG, Hyatt AD, Speare R, Coupar BEH (1993) Comparison of epizootic haematopoietic necrosis and Bohle iridoviruses, recently isolated Australian iridoviruses. Dis Aquat Org 15:93-107

Hyatt AD, Eaton BT, Hengstberger SG, Russel G (1991) Epizootic haematopoietic necrosis virus: detection by ELISA, immunohistochemistry and electron microscopy. J Fish Dis 14:605-618 
Hyatt AD, Eaton BT, Lunt R (1987) The grid-cell culture technique: the direct examination of virus-infected cells and progeny viruses. J Microsc 145:97-106

Langdon JS, Humphrey JD, Williams LM, Hyatt AD, Westbury HA (1986) First virus isolation from Australian fish: an iridovirus-like pathogen from redfin perch, Perca fluviatilis L. J Fish Dis 9:263-268

Mao J, Hedrick RP. Chinchar VG (1997) Molecular characterization, sequence analysis, and taxonomic position of newly isolated fish iridoviruses. Virology 229:212-220

Miyata M, Matsuno $K$, Jung SJ, Danayadol Y, Miyazaki T (1997) Genetic similarity of iridoviruses from Japan and Thailand. J Fish Dis. 20:127-134

Moody NJG, Owens L (1994) Experimental demonstration of the pathogenicity of a frog virus, Bohle iridovirus, for a fish species, barramundi Lates calcarifer. Dis Aquat Org 18 95-102

Murti KG, Goohra R, Chen M (1985) Interaction of frog virus 3 with the cytoskeleton. Cur Top Microbiol lmmunol 116: $107-131$

Editorial responsibility: Peernel Zwart, Utrecht, The Netherlands
Pozet F, Morand M, Moussa A, Torhy C, Kinkelin PDe (1992] Isolation and preliminary characterisation of a pathogenic icosahedral deoxyribovirus from the catfish Ictalurus melas. Dis Aquat Org 14:35-42

Speare R, Freeland WJ, Bolton SJ (1991) A possible iridovirus in erythrocytes of Bufo marinus in Costa Rica. J Wild] Dis 27:457-462

Speare R, Smith JR (1992) An iridovirus-like agent isolated from the ornate burrowing frog Limnodynastes ornatus in northen Australia. Dis Aquat Org 14:51-57

Tripier F, Braunwald J, Markovic L, Kirn A (1974) Budding of Frog virus 3 studied by immunological and cytochemical methods in electron microscopy. Intervirology 3:305-318

Wolf K, Bullock GL, Dumbar DE, Quimby MC (1968) Tadpole edema virus: a viscerotropic pathogen for anuran amphibians. J Infect Dis 118:253-262

Zupanovic Z, Lopez G, Green B, Bartran G, Parkes H, Whittington RJ, Speare R, Hyatt AD (1998) Giant toads Bufo marinus in Australia and Venezuela have antibodies against 'ranaviruses' Dis Aquat Org 32(1):1-8

Submitted: November 15, 1997; Accepted: February 4, 1998 Proofs received from author(s): April 21, 1998 